\title{
Potential impacts of future climate change on nyala Tragelaphus angasi in Lengwe National Park, Malawi
}

\author{
Francis X. Mkanda \\ Department of National Parks and Wildlife, PO Box 30131, Lilongwe 3, Malawi
}

\begin{abstract}
General Circulation Models (GCMs) were used to develop climate change scenarios for the Lengwe National Park in Malawi. Scenarios of future precipitation and ambient temperature were in turn used to evaluate habitat suitability of 5 ungulate populations and to rank their vulnerability to global climate change in the park. Preliminary results suggest that ambient temperatures may rise with a doubling of atmospheric $\mathrm{CO}_{2}$, and precipitation will be more variable. The vulnerability assessment results suggest that all the ungulates, especially nyala antelope Tragelaphus angasi, could be highly susceptible to climate induced changes in habitat and food supply. Adaptive measures, such as translocation, culling, and expanding the water supply, may alleviate climatic change impacts on nyala and other ungulates.
\end{abstract}

KEY WORDS: Adaptation C Change - Nyala - Precipitation - Suitability - Temperature - Ungulates · Vulnerability

\section{INTRODUCTION}

The consensus that increases in the atmospheric greenhouse gases will adversely affect the global climate system is growing (Carter et al. 1994, Houghton et al. 1992). Changes in ambient temperature, precipitation patterns and soil moisture are some of the expected direct effects of climate change. Unmanaged or semi-managed ecosystems are regarded as especially vulnerable if global climate changes (Carter et al. 1994). Ominde \& Juma (1991) asserted that wildlife is a key natural resource that might be susceptible to climate change. In Malawi, where wildlife management and ecotourism are integral parts of the land use system, assessment of potential vulnerability to climate change is an integral step in environmental planning. Designated wildlife areas occupy approximately $22 \%$ of Malawi's land area as national parks, wildlife reserves, and forest reserves (Mkanda 1991, Mkanda \& Munthali 1994).

Recently, there have been 3 significant droughts (in 1978-79, 1981-82, and 1991-92) that have affected wildlife in habitat in southern Africa including Malawi. The impacts of droughts were regionally variable, but often devastating to wildlife populations. One drought effect in Lengwe National Park was overcrowding of wildlife at water holes, leading to overgrazing of foliage which induced changes to the plant community structure. In extreme cases animal mortality occurred, including loss of the nyala antelope Tragelaphus angasi in Lengwe National Park (Mkanda \& Munthali 1991).

A preliminary global climate change vulnerability analysis of 5 ungulate populations of Lengwe National Park appears to show that the nyala could be the most vulnerable species (Western 1991, Mkanda 1996). Therefore, the potential impacts of climate change on nyala and several other ungulates were assessed using a scenario-based analysis. Specifically, the study assessed potential changes in habitat suitability under different climate scenarios and examined possible adaptive measures.

\section{STUDY SITE}

Lengwe National Park was selected because of its current extreme climatic conditions, and because future scenarios for this region depict hotter and drier 


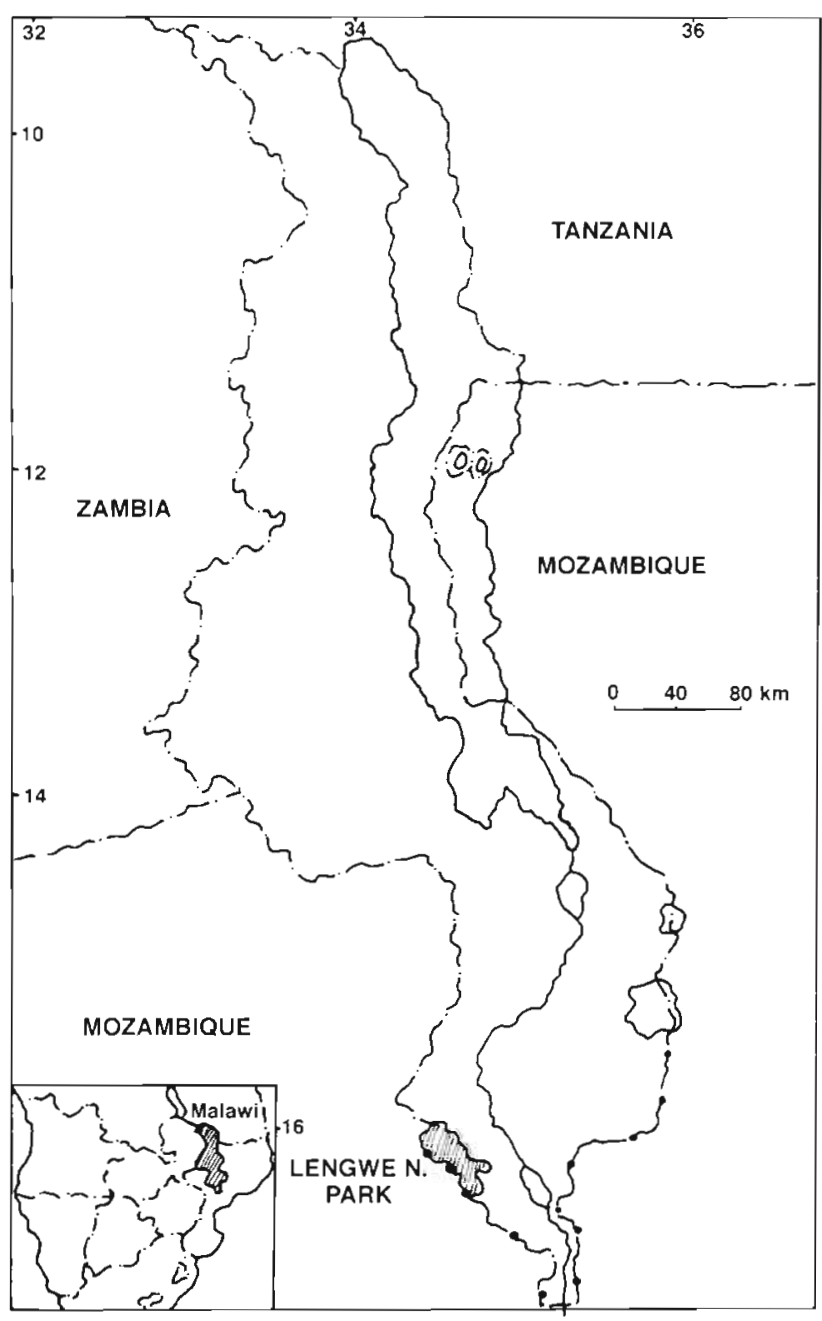

Fig. 1. Location of Lengwe National Park in Malawi

weather than the current climate (Fig. 1). The park $\left(887 \mathrm{~km}^{2}\right.$ in size) lies in the Lower Shire Valley (southern Malawi) at an altitude of between 30 and $100 \mathrm{~m}$ above sea level. Lengwe has a semi-arid type of climate (Hulme et al. 1994). The minimum mean temperature is $16^{\circ} \mathrm{C}$ in June, while the mean maximum is $36^{\circ} \mathrm{C}$ in November. Precipitation ranges from $84 \mathrm{~mm}$ in September to $2136 \mathrm{~mm}$ in December. The annual mean monthly rainfall is $700 \mathrm{~mm}$. These climate parameters represent the highest and the lowest temperature and the most erratic rainfall patterns in Malawi (Anonymous 1975). Mkanda et al. (1988) observed that during drought years the mean annual precipitation falls below $500 \mathrm{~mm}$. This phenomenon has occurred twice in the past $13 \mathrm{yr}$.

The eastern portion of Lengwe National Park, also known as 'Old Lengwe', occupying an area of only $104 \mathrm{~km}^{2}$, is nyala habitat (Mkanda \& Munthali 1991). The soils are derived from upland drift deposits, consisting of sand, clay loams, and sandy loams (Clarke
1983). Acacia thicket-clump savanna, inhabited by the tree species Acacia nigrescens, Albizia harveyi, and Dalbergia melanoxylon, is the primary vegetation

Lengwe National Park ecosystems are described by Munthali (1991). The park has several ungulate species including 2000 buffaloes Syncerus caffer, 300 kudus Tragelaphus strepsiceros, 1300 warthogs Phachoecorus aethiopicus, and 1000 impalas Aepyceros melampus. Reptiles, small mammals, and birds are also common throughout the park. The nyala is a key species in the park, numbering approximately 2000. Another small population of nyala occurs in a small reserve about $50 \mathrm{~km}$ south of Lengwe. Movement between the 2 populations does not occur because the intervening corridor has been heavily settled (Mkanda \& Munthali 1991).

\section{MATERIALS AND METHODS}

Four General Circulation Models (GCMs) were employed in this scenario-based analysis (Unganai 1996; this issue). The scenarios were developed from the following models: the Canadian Climate Center (CCC) model (Boer et al. 1992), the GFD3 model from the Geophysical Fluid Dynamic Laboratory (Manabe \& Wetherald 1987), the Goddard Institute for Space Sciences (GISS) model (Hansen et al. 1983), and the United Kingdom Meteorological Office UK89 model (Mitchell et al. 1989). As in the baseline (existing climate) scenario, the precipitation and temperature data from 3 grid points were averaged for each model. Current precipitation and temperature data for the period 1951 to 1980 were obtained from the International Institute of Applied Systems Analysis (IIASA) database (Unganai 1996). Three grid points $\left(34^{\circ} 00^{\prime} \mathrm{E}, 16^{\circ} 30^{\prime} \mathrm{S}\right.$; $34^{\circ} 30^{\prime} \mathrm{E}, 16^{\circ} 30^{\prime} \mathrm{S} ;$ and $35^{\circ} 00^{\prime} \mathrm{E}, 16^{\circ} 30^{\prime} \mathrm{S}$ ) that are adjacent to Lengwe National Park were averaged and employed as the baseline (existing climate) scenario.

The mean $1 \times \mathrm{CO}_{2}$ model outputs and the spatially averaged precipitation and temperature data were plotted and comparisons of seasonal climate patterns with the GCM outputs were made (see Figs. 3 \& 4). Four GCMs (GFD3, GISS, CCC, UK89) were considered useful in simulating the current climate in the study area (Unganai 1996). To develop climate change scenarios, changes in ambient temperature patterns were analyzed in comparison to existing climate (Unganai 1996). Precipitation pattern changes were computed as the ratio $\left(2 \times \mathrm{CO}_{2}\right):\left(1 \times \mathrm{CO}_{2}\right)$.

Millsap et al. (1990) used 16 variables to provide a vulnerability ranking of all vertebrate taxa in Florida, USA. This study employed similar variables to rank vulnerability of 5 ungulates occurring in Lengwe $\mathrm{Na}$ tional Park: nyala, impala, buffalo, warthog, and kudu. 
These ungulates were chosen for the analysis because of their prominent role in park ecosystems (Mkanda \& Munthali 1991, Munthali 1991). Biological scores were obtained from the sum of individual scores for 7 variables that reflected different facets of distribution, abundance and life history (see Table 2). Action scores were the sum of individual scores for 4 variables that reflected the current ecological knowledge about the taxon. Five supplemental variables were used to sort and categorize taxa to answer specific questions about a taxon behavior (Munthali 1991). Variable scores ranged from 0 to 10 (10 denoting high vulnerability).

The Habitat Suitability Index (HSI) method was used to evaluate the nyala habitat under each climate scenario (U.S. Fish and Wildlife Service 1981). The HSI method relates the suitability of habitat variables of a landscape to the animal species of concern and assigns an index of suitability. Values of HSI range from 0 (completely unsuitable) to 1 (optimally suitable). To detect the total HSI under the present climate, several parameters were developed: annual precipitation, preferred browse height, the number of preferred browse/grass species, area of the park burned as part of management policy, mean annual temperature, area of thicket cover, distance to water, and degree of illegal incidents (number of snares, gunshots, carcasses, and poacher sightings). A number of assumptions regarding HSI were developed based on conditions described in the following paragraphs (see Table 3).

Since up to $2136 \mathrm{~mm}$ of precipitation occurs in the park, and drought strikes when the annual precipitation falls below $500 \mathrm{~mm}$, any precipitation of up to $2000 \mathrm{~mm}$ would be considered optimally suitable under any climate change scenario. The suitability index (SI) would therefore be 1. In contrast annual precipitation of less than $500 \mathrm{~mm}$ would be unsuitable $(0)$.

Field observations have shown that the preferred browse height of nyala is $1.0 \mathrm{~m}$. During times of drought, however, the nyala browses up to $2.0 \mathrm{~m}$. Therefore, $1.0 \mathrm{~m}$ was taken as the optimum suitable browse height. Inversely, suitability would be considered to increase with a decrease in height. Under climate change, therefore, an increase in browse height would make the habitat unfavorable while a decrease would increase habitat suitability for nyala.

Munthali (1991) reported that the nyala prefer to browse 16 plant species in Lengwe National Park. Therefore, with climate change, the habitat would be suitable if nyala had about 16 browse species or more. In contrast, it could become unsuitable if there were $<15$ species.

The recommended vegetation burning policy is that $1 / 3$ of the park is burned early in the season, $1 / 3$ is burned late, and another $1 / 3$ is left unburned. For a park of $104 \mathrm{~km}^{2}$ size, 30 to $60 \mathrm{~km}^{2}$ of open space is suitable; below or above is considered unsuitable. The interpretation of suitability would remain unchanged under any climate change scenario.

Thicket clumps, which occupy about half the park, are nyala habitat in Lengwe. Therefore, a thicket cover of between 50 and $100 \mathrm{~km}^{2}$ is suitable. Suitability declines if thicket cover falls below $50 \mathrm{~km}^{2}$. If the thicket cover were to decrease under climate change, the habitat would be unsuitable. If the cover were to increase, however, the habitat would be optimally suitable.

The park has artificial water holes spaced on average at a distance of $5 \mathrm{~km}$. Therefore, a distance of 5 to $10 \mathrm{~km}$ is considered as suitable. The suitability declines above $10 \mathrm{~km}$ and below $5 \mathrm{~km}$. Under climate change, a distance of between 5 and $10 \mathrm{~km}$ would still be deemed suitable, but any decrease (because the area would be too wet) or increase in distance would be considered unsuitable.

Illegal poaching data were categorized as follows: low, 30 incidents per year; medium, 31 to 60 incidents; and high, $>60$ incidents. These values were then converted to $0=$ high, $1=$ medium, and $2=$ low. The habitat is suitable if the incidents are low, but the index declines as the number of incidents increases. The same conditions would apply under climate change.

Finally, suitability indices for temperature were determined from the mean minimum and maximum temperatures of 16 and $36^{\circ} \mathrm{C}$ respectively. Any departure from this range is regarded as unsuitable. Under climate change, therefore, temperatures that would be lower or higher than the present range would reduce habitat suitability.

The suitability indices at which the habitat was thought suitable were aggregated (Fig. 2) to calculate the overall $\mathrm{HSI}$ as the geometric mean $\left(\mathrm{HSI}=\mathrm{SI}_{1} \times \mathrm{SI}_{2}\right.$ $\left.\times \mathrm{SI}_{3} \times \ldots \mathrm{SI}_{n}\right)^{1 / n}$. For example, the suitability index using the GFD3 model was 0.86 . This was derived from

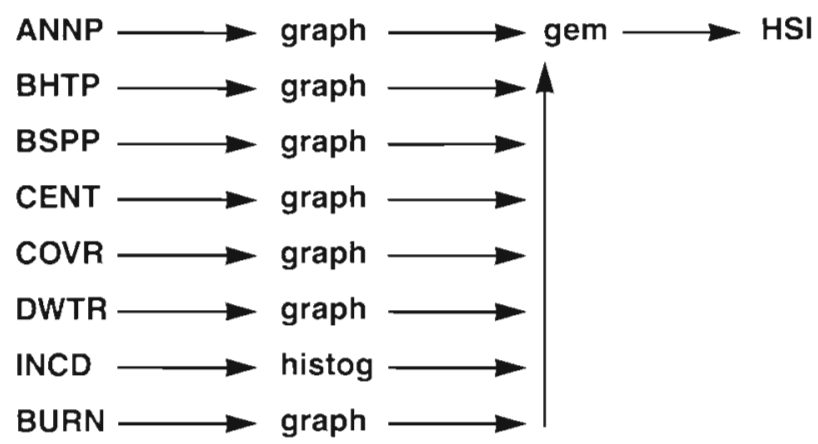

Fig. 2. Schematic diagram of aggregated nyala habitat model. ANNP: annual precipitation (mm); BHTP: preferred browsing height $(\mathrm{m})_{i}$ BSPP: preferred browse species; CENT: temperature $\left({ }^{\circ} \mathrm{C}\right)$; COVR: thicket cover $\left(\mathrm{km}^{2}\right)$; DWTR: distance to water $(\mathrm{km})$; INCD: degree of illegal incidents; BURN: park area burned $\left(\mathrm{km}^{2}\right)$; histog: histogram; gem: geometric mean 
the geometric mean of the suitability indices of the following parameter values: precipitation range of between 500 and $2000 \mathrm{~mm}$, a preferred browsing height of $1.5 \mathrm{~m}$, number of browsing/grazing species being $15,60 \mathrm{~km}^{2}$ of the park area burned, a temperature range of 16.4 to $36.2^{\circ} \mathrm{C}$, a thicket cover of $75 \mathrm{~km}^{2}, 9 \mathrm{~km}$ between water, and low incidents with a value of 2 . To detect habitat suitability under each climate change scenario, the annual precipitation and mean temperature data derived from each GCM were used in the habitat model. This made it possible to determine the impact of changes in precipitation and temperature on habitat (Hulme et al. 1994).

\section{RESULTS}

Generally, the GCM scenarios suggest that ambient temperatures will rise within the study area; the temperature increase ranges from 2.8 to $3.1^{\circ} \mathrm{C}$ (Table 1 ).

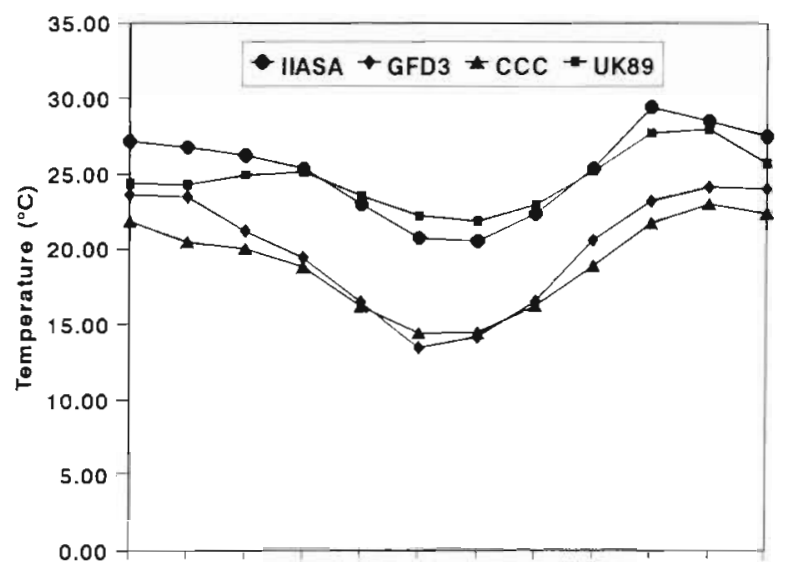

Jan Feb Mar Apr May Jun Jul Aug Sep Oct Nov Dec

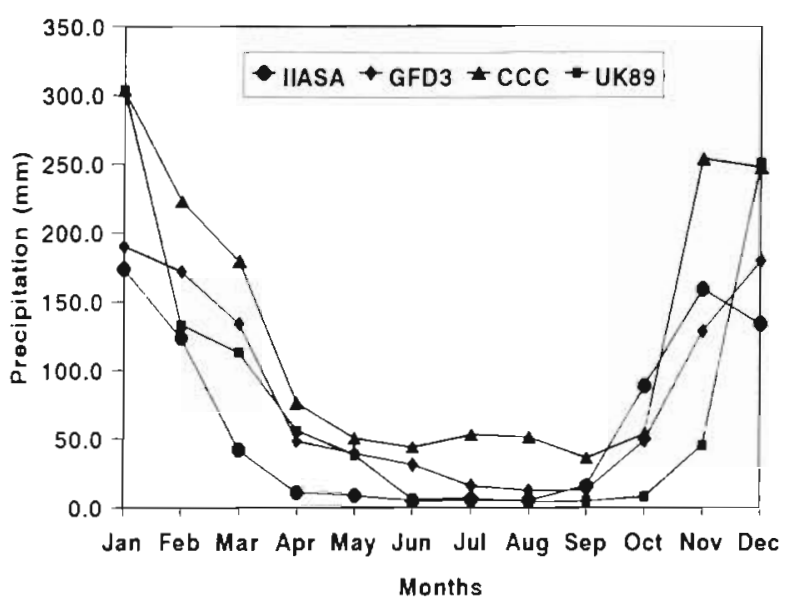

Fig. 3. Ambient temperature and precipitation patterns of existing climate (IIASA) in comparison to $1 \times \mathrm{CO}_{2}$ scenarios of 3 GCMs (GFD3, CCC, UK89)
Table 1 . Changes (difference between $1 \times$ and $2 \times \mathrm{CO}_{2}$ ) in precipitation and ambient temperature patterns under 3 climate change scenarios in Malawi

\begin{tabular}{|lcc|}
\hline Model & $\Delta$ temperature $\left({ }^{\circ} \mathrm{C}\right)$ & $\Delta$ precipitation $(\%)$ \\
\hline GFD3 & 3.1 & 12.8 \\
CCC & 3.1 & -11.0 \\
UK89 & 2.8 & -0.7 \\
\hline
\end{tabular}
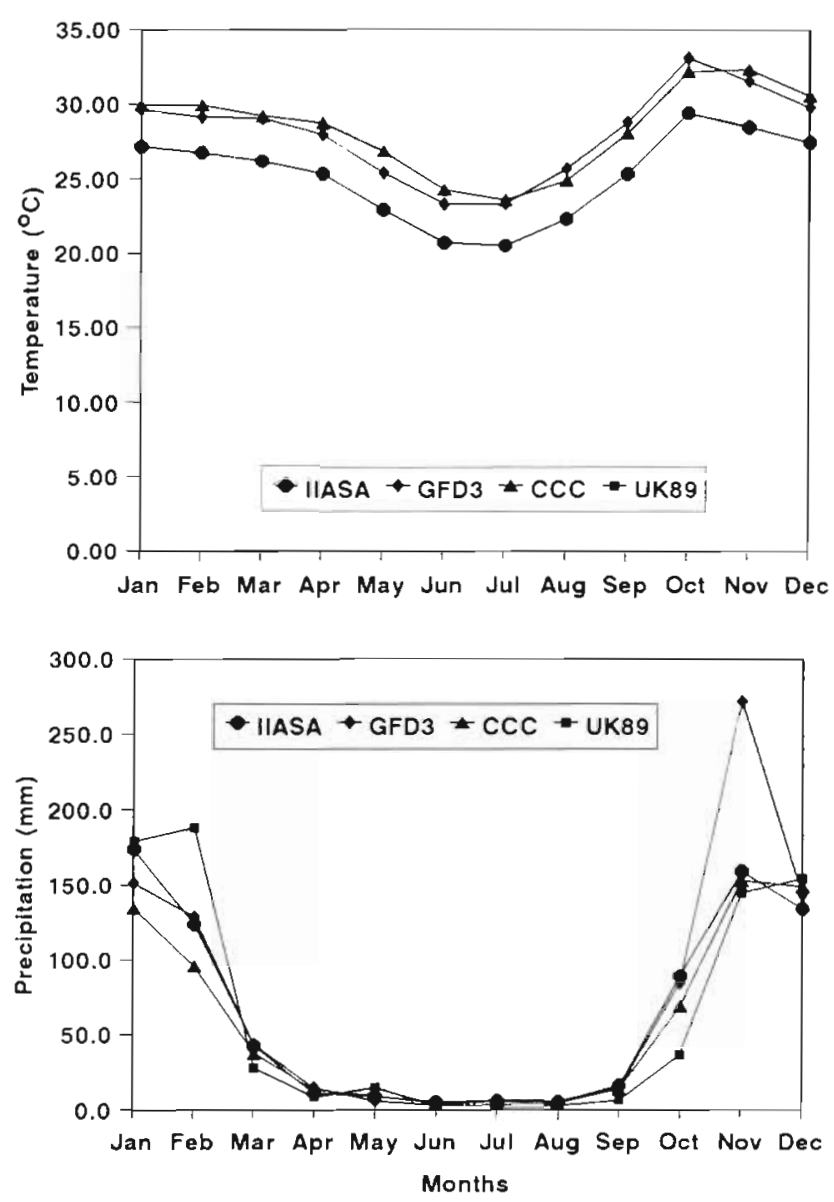

Fig. 4. Ambient temperature and precipitation pattern of existing climate (IIASA) in comparison to $2 \times \mathrm{CO}_{2}$ scenarios of 3 GCMs (GFD3, CCC, UK89)

Two models (UK89, CCC) imply a decline in annual precipitation under climate change scenarios, the latter depicting a greater $(11 \%)$ precipitation deficit than the former. Only the GFD3 model depicts an increase in annual precipitation (12.8\%).

The GCM scenarios also predict similar seasonal trends of annual precipitation and ambient temperature under both baseline and climate change scenarios (Figs. $3 \& 4$ ). The general trend is frequent precipitation at the onset of the rainy season in November continuing until January. The Chiperoni rains, which are 
Table 2. Population vulnerability assessment scores of 5 ungulates in Lengwe National Park, Malawi. Values range from 0 to 10 (10 denoting high vulnerability)

\begin{tabular}{|c|c|c|c|c|c|}
\hline \multirow{2}{*}{ Variable } & \multirow[b]{2}{*}{ Nyala } & \multirow[b]{2}{*}{ Buffalo } & \multirow{2}{*}{$\begin{array}{l}\text { Score } \\
\text { Kudu }\end{array}$} & \multirow[b]{2}{*}{ Warthog } & \multirow[b]{2}{*}{ Impala } \\
\hline & & & & & \\
\hline \multicolumn{6}{|l|}{ Biological } \\
\hline 1 Population sıze & 6.0 & 6.0 & 6.0 & 10.0 & 8.0 \\
\hline 2 Population trend & 6.0 & 0 & 6.0 & 6.0 & 0 \\
\hline 3 Range size & 10.0 & 9.0 & 9.0 & 9.0 & 10.0 \\
\hline 4 Distribution trend & 2.0 & 0 & 2.0 & 0 & 0 \\
\hline 5 Population concentration & 6.0 & 6.0 & 0 & 0 & 6.0 \\
\hline 6 Reproductive potential & 3.0 & 3.0 & 3.0 & 3.0 & 3.0 \\
\hline 7 Specialization & 3.3 & 0 & 1.7 & 0 & 0 \\
\hline Total $(\max .70 .0)$ & 36.3 & 24.0 & 27.7 & 28.0 & 27.0 \\
\hline \multicolumn{6}{|l|}{ Action } \\
\hline 1 Knowledge of distribution & 0 & 0 & 0 & 0 & 0 \\
\hline 2 Knowledge of population trend & 6.0 & 6.0 & 6.0 & 6.0 & 6.0 \\
\hline 3 Knowledge of population limitation & 5.0 & 5.0 & 5.0 & 5.0 & 5.0 \\
\hline 4 Management activities & 0 & 5.0 & 5.0 & 0 & 5.0 \\
\hline Total (max. 40.0) & 11.0 & 16.0 & 16.0 & 11.0 & 16.0 \\
\hline \multicolumn{6}{|l|}{ Supplemental } \\
\hline 1 Significance of taxon & 3.0 & 4.0 & 3.0 & 3.0 & 3.0 \\
\hline $2 \%$ of range in the park & 5.0 & 1.0 & 1.0 & 1.0 & 1.0 \\
\hline 3 Trend in park population & 2.0 & 2.0 & 2.0 & 5.0 & 4.0 \\
\hline 4 Period of occurrence & 4.0 & 4.0 & 4.0 & 4.0 & 4.0 \\
\hline 5 Harvest of taxon & 1.0 & 1.0 & 1.0 & 1.0 & 1.0 \\
\hline Total (max. 24.0) & 20.0 & 20.0 & 10.0 & 20.0 & 10.0 \\
\hline Grand total (max. 134.0) & 67.3 & 60.0 & 53.7 & 59.0 & 53.0 \\
\hline
\end{tabular}

dry-season precipitation brought by high-pressure southeasterly winds, dominate in winter (May to July). Ambient temperatures are usually above $25^{\circ} \mathrm{C}$ during most of the year except between May and August, when declining to $20^{\circ} \mathrm{C}$. Under both climate change scenarios $\left(1 \times \mathrm{CO}_{2}\right.$ and $\left.2 \times \mathrm{CO}_{2}\right)$, all models, except the GFD3, do not exhibit significant departure from the current precipitation and temperature trends. The GFD3 climate change scenario depicts higher precipitation than both the existing and $2 \times \mathrm{CO}_{2}$ scenarios at the onset of the rainy season (Fig. 4).

Using the Millsap et al. (1990) method, all of the ungulates may be vulnerable to climate change. The nyala may be the species most vulnerable to global climate change in Lengwe National Park. The impala appears to be the least vulnerable, followed by buffalo and kudu in this ecosystem (Table 2). The variables also suggest that the nyala and warthog may have more specific niche requirements. The supplemental variables contribute insignificantly to the sum of the scores.
The HSI appears to decline for Lengwe National Park species under 3 of the climate change scenarios (Table 3). HSI is not drastically different among GCMs. For example, there is only a difference of 0.06 between the baseline scenario and the UK89 model climate change scenario, which gives the lowest suitability index. The GFD3 and CCC models depict similar future habitat conditions.
Table 3. Nyala habitat suitability indices (HSI) under existing and climate change scenarios in Malawi

\begin{tabular}{|lrrrr|}
\hline Variable & Baseline & GFD3 & CCC & UK89 \\
\hline Annual precipitation $(\mathrm{mm})$ & 773.0 & 872.0 & 768.0 & 688.0 \\
Temperature $\left({ }^{\circ} \mathrm{C}\right)$ & 25.2 & 28.3 & 28.0 & 28.4 \\
Browse height $(\mathrm{m})$ & 1.5 & 1.5 & 1.5 & 1.5 \\
Preferred browse species & 10.0 & 10.0 & 10.0 & 10.0 \\
Area burnt $\left(\mathrm{km}^{2}\right)$ & 60.0 & 60.0 & 60.0 & 60.0 \\
Thicket cover $\left(\mathrm{km}^{2}\right)$ & 75.0 & 75.0 & 75.0 & 75.0 \\
Distance to water $(\mathrm{km})$ & 9.0 & 9.0 & 9.0 & 9.0 \\
Illegal incidents $(\mathrm{no})$. & 2.0 & 2.0 & 2.0 & 2.0 \\
HSI & 0.9 & 0.9 & 0.9 & 0.8 \\
\hline
\end{tabular}




\section{DISCUSSION}

Two of the climate change scenarios suggest that there will be lower precipitation in Lengwe National Park. Although the GFD3 model predicts increased precipitation, rising ambient temperatures will probably increase evapotranspiration rates, reduce water availability and reduce vegetation productivity (Hulme et al. 1994). Coe et al. (1976) and Western (1991) have demonstrated that there is a positive correlation between animal biomass, vegetation production and rainfall. The implication of the GCM scenarios is that lower precipitation would lead to declines in vegetation and animal biomass (Munthali 1991).

Depicting the consequences of global climate change on nyala is difficult due to ecosystem complexity (Western 1991). Methods that can directly link animal population vulnerability with habitat indices (e.g. HSI) are yet to be developed. There may not be any direct climate impact on the nyala due to changes in ambient temperature or precipitation patterns. Climate change may indirectly affect other habitat variables such as distance to water, thicket cover, composition of browse and grass species, and browse height, causing degradation in habitat suitability (Mkanda \& Munthali 1991). Climate change will also have implications for other animal species including predators. Sensitivity testing is required to depict changes in HSI as habitat variable values change. Secondly, sensitivity testing would help identify critical adaptive measures to climate change vulnerability (Markham 1996; this issue).

Nyala is a vulnerable species that may not adapt to climate-induced habitat changes easily. Evidence from past droughts seems to support this assumption. Between November and December 1980, 50 to 100 nyala died in Lengwe National Park (Mkanda \& Munthali 1991). This was attributed to the drought of 1980 (total annual precipitation of $477 \mathrm{~mm}$ ), which resulted in poor regeneration of the vegetation. A combination of a high nyala population and low rainfall led to unsatisfactory habitat conditions. Similarly, under climate change scenarios, any decline in annual precipitation to the level of 1980 , assuming a large nyala population, would lead to a drastic decline in the general habitat suitability. However, small populations could also become vulnerable for reasons other than climate change (e.g. inbreeding depression).

The models employed in this analysis may not necessarily reflect the actual magnitude of future ecosystem change (Carter et al. 1994). However, the HSI seems to decline under all the scenarios. Since the baseline precipitation and temperature scenarios were developed using a long-term database, there is some degree of confidence in the scenario results. The general trend in habitat suitability declines as opposed to growing variability of extreme events ( 3 GCM scenarios show that temperature may rise)

\section{SUMMARY AND ADAPTATION OPTIONS}

The scenarios show that as climate changes, particularly ambient temperature, habitat loss increases. Therefore, adaptive measures should aim at alleviating the negative impacts of these changes. Ecosystems may adapt to climate change without human intervention. Caughley \& Walker $(1983 \mathrm{a}$, b) assert that to prevent change, more management effort would be needed in the future. Reducing temperature or increasing precipitation locally to improve habitat suitability is not possible in Lengwe National Park. Assuming the worst climate change scenario depicted by Hulme et al. (1994) for southern Africa (water deficits attributable to climate change), animal mortality would be significant, particularly if populations were near carrying capacity. Therefore conventional wildlife management techniques such as translocation, provision of artificial water supplies, culling, and trophy hunting may be useful management tools should intervention become necessary,

Translocation as a wildlife management tool has been widely applied during times of drought, but it would probably be of limited application under changed climate conditions since these will be characterized by a general drought condition (Walker et al. 1987). Secondly, within Malawi, translocation could only be to an adjacent wildlife reserve (Mwabvi) capable of holding only a small translocated population. Translocating the nyala to Mwabvi may have genetic implications for breeding populations. Caughley \& Waiker $(1983 a, b)$ state that species comprise sub-populations that are genetically distinct and may possess adaptive characteristics for their particular environments. Introduction of populations from elsewhere leads to mixing of 2 incompatible gene complexes (inferior vs superior competitors). Translocation to other parts of Malawi would pose ecological problems because of habitat limitations. The only other option would be to translocate the animals to a zoo, safari parks or intensively managed wildlife ranches.

Provision of artificial water supplies would help alleviate the impacts of water deficits if applied as an anticipatory adaptation measure (Walker et al. 1987). This could reduce access of animals to water. However, provisional supply would be of limited value as a reactive measure when the climate has changed because water tables decline, making underground water extraction costs prohibitive. Provision of animal drinking water alone would also not help forage production, which is likely to decrease with low precipitation. 
Since animal biomass and habitat suitability may decline because of low precipitation associated with climate change (Coe et al. 1976), culling to reduce animal numbers to acceptable management limits might be a viable option. Studying impacts of droughts on some conservation areas in southern Africa, Walker et al. (1987) asserted that culling was ecologically unnecessary where sufficient spatial heterogeneity existed to provide reserve forage. The GCM scenarios analyzed in this study imply that water deficits would be continuous. Therefore, plant biomass production would decline, making long-term survival of most of the herbivores questionable. The disadvantage of culling is that it does not necessarily help animals adapt to climate change. Culling also reduces genetic variability, which could be a problem when the population tries to recover. However, culling helps to reduce animal populations and maintain them within carrying capacity (Kombe 1983).

Whether adaptation should be anticipatory or reactive is an important question but difficult to answer from the climate change scenarios analyzed in this study (Carter et al. 1994, Mkanda 1996). If one or all of these options are chosen, anticipatory adaptation would mean carrying out measures in anticipation of climate change. In contrast, reactive adaptation would involve taking corrective measure in response to climate change. It is premature to recommend either option in Malawi at this time (Magadza 1994). This study may help to confirm how difficult it is to choose either an anticipatory or reactive adaptive strategy. Both adaptive strategies have been applied in the culling of nyala in Lengwe National Park and each became highly controversial (Kombe 1983, Mkanda \& Munthali 1991).

\section{LITERATURE CITED}

Anonymous (1975) An atlas of the Shire Valley. Department of Surveys, Blantyre, Malawi

Boer GJ, McFarlane NA, Lazaro M (1992) Greenhouse gasinduced climate change simulated with the CCC second generation general circulation model. Bull Am Meteorol Soc 5:1045-1077

Carter TR, Parry ML, Harasawa H, Nishioka S (1994) Intergovernmental panel on climate change technical guidelines for assessing climate change impacts and adaptation. University College London and Center for Global Environmental Research, London

Caughley GBH, Walker BH (1983a) Guidelines for the management of large mammals in African conservation areas. In: Ferrar AA (ed) Guidelines for the management of large mammals in African conservation areas. South African National Scientific Programmes Rep no. 69. Council for Scientific and Industrial Research, PIetoria, $\mathrm{p}$ iv

Caughley GBH, Walker BH (1983b) Working with ecological ideas. In: Ferrar AA (ed) Guidelines for the management of large mammals in African conservation areas. South African National Scientific Programmes Rep no. 69. Council for Scientific and Industrial Research, Pretoria, p 32
Clarke JE (1983) Protected areas master plan for the southern region. Department of National Parks and Wildlife, Lilongwe

Coe MJ Cumming DHM, Phillipson J (1976) Biomass production of African herbivores in relation to rainfall and primary production. Oecologia 22:341-354

Hansen J, Russell G, Rind D, Stone P, Lacis A, Lebedeff $S$, Ruedy R, Travis L (1983) Efficient three-dimensional global models for climate studies: models I and II. Mon Weather Rev 111:609-662

Houghton JT, Callendar B, Varney SK (eds) (1992) Climate change 1992: the IPCC supplementary report on the IPCC scientific assessment. Cambridge University Press, Cambridge

Hulme M, Conway D, Kelly PM, Subak S, Downing TE (1994) The impacts of climate change on Africa. Center for Social and Economic Research on the Global Environment Working Paper GEC 95-04. University of East Anglia, Norwich

Kombe ADC (1983) Government and public reactions to culling in conservation areas in Malawi. In: Owen-Smith R (ed) Management of large mammals in African conservation areas. Dept of Environment and Tourism, Pretoria

Magadza CHD (1994) Climate change: some likely multiple impacts in Southern Africa. Food Policy 19(2):165-191

Manabe S, Wetherald RT (1987) Large scale changes in soil wetness induced by an increase in carbon dioxide. J Atmos Sci 44:1211-1235

Markham A (1996) Potential impacts of climate change on ecosystems: a review of implications for policymakers and conservation biologists. Clim Res 6:179-191

Millsap BA, Gore JA, Runde DE, Cerulean SI (1990) Setting priorities for the conservation of fish and wildlife species in Florida. Wildl Monogr 111:1-57

Mitchell JFB, Senior CA, Ingram WJ (1989) $\mathrm{CO}_{2}$ and climate: a missing feedback. Nature 341:132-134

Mkanda FX (1991) The wildlife industry in Malawi with respect to meat supply, In: Munthali JTK, Mtukuso AP, Msiska HDC (eds) Proceedings of the first national workshop on livestock production in Malawi. Ministry of Agriculture, Lilongwe, p 9-21

Mkanda FX (1996) Potential income and food security for communities neighboring Kasungu National Park, Malawi. Environ Conserv (in press)

Mkanda FX, Munthali SM (1991) Mortality of nyala (Tragelaphus angasi) in Lengwe National Park, Malawi. Afr J Ecol $29: 28-36$

Mkanda FX, Munthali SM (1994) Public attitudes and needs around Kasungu National Park, Malawi. Biodiver Conserv $3: 29-44$

Mkanda FX, Munthali SM, Chiwona EA (1988) A review of the culling of nyala (Tragelaphus angasi) in Lengwe National Park. Department of National Parks and Wildlife, Lilongwe, p 59

Munthali SM (1991) The feeding habits of nyala (Tragelaphus angasil in Lengwe National Park, Malawi. Nyala 15(1): $17-23$

Munthali SM, Mughogho DEC (1992) Economic incentives for conservation - an experiment on bee-keeping and Saturniidae caterpillar utilization by rural people. Biodiver Conserv 1:143-54

Ominde SH, Juma C (1991) A change in the weather. In: Ominde $\mathrm{SH}$, Juma $\mathrm{C}$ (eds) A change in the weather: African perspectives on climatic change. ACTS Press, Nairobi, p 3-12

Unganai LS (1996) Historic and future climatic change in Zimbabwe. Clim Res 6:137-145 
US Fish and Wildlife Service (1981) Standards for the development of habitat suitability index models, 103 ESM. US Fish and Wildife Service, Division of Ecological Services, Washington, DC

Walker BH, Emslie RH, Owen-Smith RN, Scholes RJ (1987) To cull or not to cull: lessons from a southern African drought J Appl Ecol 24:381-401

Western D (1991) Climatic change and biodiversity. In: Ominde SH, Juma $\mathrm{C}$ (eds) A change in the weather. African Center for Technology Studies, Nairobi, p 87-96 